\title{
Efficacy of indigenous strain of entomopathogenic nematode against diapausing larvae of Codling moth, Cydia pomonella L. (Lepidoptera: Tortricidae), in apple-growing hilly areas of Ladakh Region
}

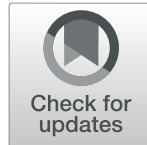

\author{
Mohammad Jamal Ahmad ${ }^{1 *}$, Sajad Mohiudin ${ }^{2}$, Tarique Hassan Askary ${ }^{3^{*}}$ and Jagadeesh Patil ${ }^{4}$
}

\begin{abstract}
Indigenous entomopathogenic nematode, Heterorhabditis pakistanensis, NBAIR H-05 strain was evaluated against diapausing larvae of the Codling moth, Cydia pomonella L. (Lepidoptera: Tortricidae) at 3 different dosages, i.e., at 15, 20, and $25 \mathrm{gm} /$ I of water in apple orchards at the district Kargil of Ladakh Region, India, during 2017 and 2018.Two year's pooled average density of diapausing ranged 34.6 to 56.8 larvae/trunk band before treatment, which declined ranging 43.85 to $86.27 \%$ with respect to different treatments of entomopathogenic nematode at concentrations between $7.5 \times 10^{5} \mathrm{IJs}$ to $1.25 \times 10^{6} \mathrm{IJ} /$ tree. Percent reduction in larvae over control varied from 41.78 to $85.77 \%$ for $7.5 \times 10^{5} \mathrm{IJs}$ and $1.25 \times 10^{6} \mathrm{IJs}$ respectively. Two-year pooled data indicated larval mortality between 39.85 and $73.38 \%$ and 4.0 to $12.89 \%$ with respect to different treatments at 48 and $72 \mathrm{~h}$ respectively, with statistically significant difference $(P=<0.001)$. Increase in dosage of nematode formulation from $15 \mathrm{gm}$ to $25 \mathrm{gm}$ resulted in increased larval mortality $\left(r=0.92^{* *}\right)$. Post wetting of trunk band after $24 \mathrm{~h}$ in each treatment resulted in significantly higher larval mortality than non-post wetting. There was non-significant difference $(t=0.83)$ between larval mortality with respect to treatments during 2017 and 2018.
\end{abstract}

Keywords: Apple, Cydia pomonella, Entomopathogenic nematode, Heterorhabditis pakistanensis, Larval mortality, Biological control

\section{Background}

Codling moth, Cydia pomonella L. (Lepidoptera: Tortricidae), is one of the most serious pests in majority of applegrowing regions of the world (Giliomee and Riedl, 1999). In India, its distribution is however confined only in Ladakh Region of Jammu and Kashmir. The pest is believed to have

\footnotetext{
*Correspondence: ahmad_j@rediffmail.com; tariq_askary@rediffmail.com 'Division of Entomology, Faculty of Horticulture, Sher-e-Kashmir University of Agricultural Sciences and Technology, Shalimar, Srinagar, Jammu and Kashmir 190025, India

${ }^{3}$ Division of Entomology, Faculty of Agriculture, Sher-e-Kashmir University of Agricultural Sciences and Technology, Wadura Campus, Sopore, Jammu and Kashmir 193201, India

Full list of author information is available at the end of the article
}

entered the Ladakh Region from north western border of Pakistan and Afghanistan (Malik et al. 1972). It is reported to cause $60-80 \%$ fruit injuries in temperate regions of the world in neglected orchards (Shahnawaz et al. 2014). Due to their disastrous nature, C. pomonella has been declared as a quarantine pest and there is a total embargo on the movement of fruit outside or in the adjoining areas of Ladakh Region.

Ahmad et al. (2018) reported that C. pomonella completes two and a half generations a year in Ladakh, whereas in South Africa, it completes up to 4 generations in a year (Blomefield, 2003). In Ladakh, the first and second generations of $C$. pomonella remain active during June and July and a partial third generation commences

\section{Springer Open}

(- The Author(s). 2020 Open Access This article is licensed under a Creative Commons Attribution 4.0 International License, which permits use, sharing, adaptation, distribution and reproduction in any medium or format, as long as you give appropriate credit to the original author(s) and the source, provide a link to the Creative Commons licence, and indicate if changes were made. The images or other third party material in this article are included in the article's Creative Commons licence, unless indicated otherwise in a credit line to the material. If material is not included in the article's Creative Commons licence and your intended use is not permitted by statutory regulation or exceeds the permitted use, you will need to obtain permission directly from the copyright holder. To view a copy of this licence, visit http://creativecommons.org/licenses/by/4.0/. 


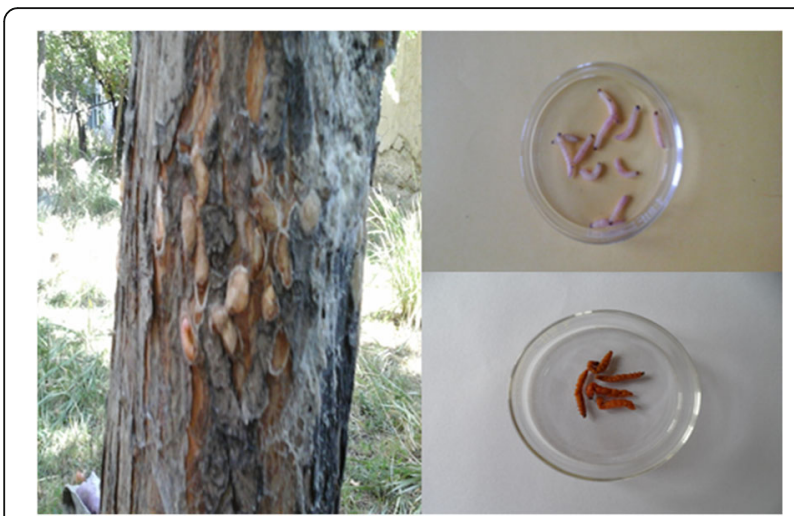

Fig. 1 ( $L$ to R): (left), Overwintering larvae of Codling moth on apple trunk (after removing trunk band); (right above) larvae collected 36 h after treatment with Heterorhabditis pakistanensis; (right below): color change in dead larvae in response to EPN treatment

from August is spent as diapause condition wherein mature larvae survives under loose barks of the trees, crevices, under the rocks or tree debris in orchard, till May of the next year (Ahmad et al. 2018). Nine month's prolonged diapausing stage of larvae, being the most susceptible stage offers a good opportunity for the management of this pest for considerable reduction of first generation population density. Overwintering larvae ranged between 35.37 and 99.56 per tree trunk up to a height of $1 \mathrm{~m}$ from ground level (Ahmad et al. 2018) is an indicative of future population level of the pest, if not targeted in time.
In the past two decades, many convenient and cost effective tactics have been developed for managing diapausing larvae of C. pomonella (Higbee et al. 2001; Cossentine et al. 2004 and Hansen et al. 2006) among them is the application of entomopathogenic nematodes (EPNs), belonging to genera Steinernema and Heterorhabditis. These biological control agents are non-hazardous, safe to humans, easy to apply, and have proved remarkably outstanding in the management of C. pomonella (Lacey and Unruh, 1998; Lacey and Chauvin, 1999; Unruh and Lacey, 2001; Cossentine et al., 2002 and Lacey et al. 2005). Lacey and Chauvin (1999) reported $100 \%$ larval mortality of $C$. pomonella treated with different dosages of Steinernema carpocapsae and S. feltiae whereas Cossentine et al. (2002) documented 93\% larval mortality with the same nematode species. De Waal et al. (2010) reported 80\% larval mortality with a local African isolate of Heterorhabditis zealandica. Odendaal et al. (2015) recorded larval mortality between 41 and $67 \%$ with 3 EPN species, $H$. bacteriophora, S. jeffreyense, and S. yirgalemense.

The present study is the first attempt in apple-growing hilly areas of Ladakh Region, India, utilizing a local strain of EPN, Heterorhabditis pakistanensis, NBAIR H05 against diapausing larvae of C. pomonella.

\section{Materials and methods}

\section{Banding of tree trunk}

The experiment was conducted in the 2 consecutive year 2017 and 2018 in 4 different apple orchards of Kargil

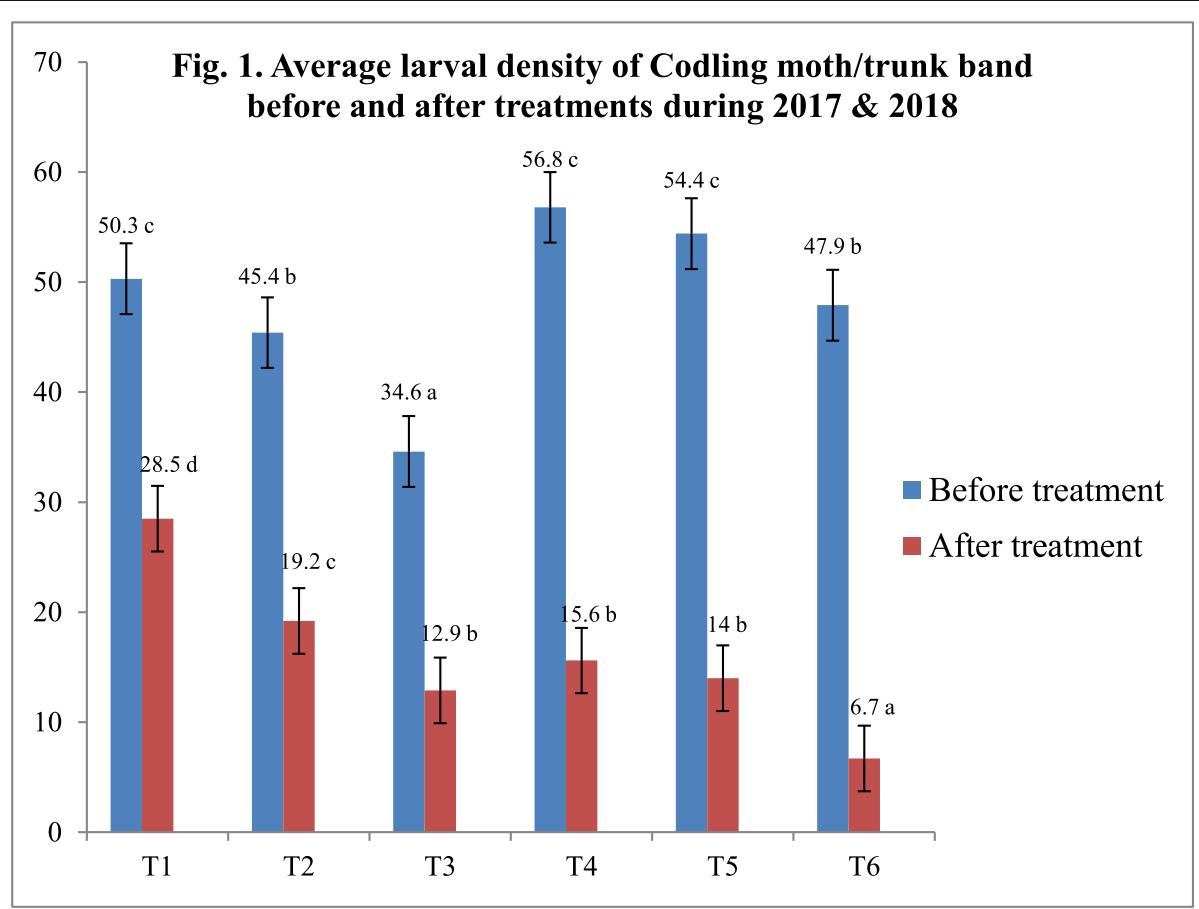

Fig. 2 Average larval density of Codling moth/tree trunk before and after treatments during the year 2017 and 2018. 
District viz., Slikchey, Shanigund, Bagh-e-Khomini, and Hardas located at $34^{\circ} 33^{\prime} 27.54^{\prime \prime} \mathrm{N}$ and $76^{\circ} 07^{\prime} 34.39^{\prime \prime}$ $\mathrm{E}$ of Ladakh Region, India. By the end of August, in each year (2017 and 2018), 10 tree trunks of each orchard were banded with gunny bags up to $1 \mathrm{~m}$ height from the ground level. The banding was performed in order to provide shelter to overwintering third generation larvae of Codling moth.

\section{Application of entomopathogenic nematode}

The freshly prepared clay formulation of local EPN strain, Heterorhabditis pakistanensis NBAIR $\mathrm{H}-05$, used in the study, was obtained from ICAR-National Bureau of Agricultural Insect Resources (NBAIR), Bengaluru, India. One gram of clay formulation contained approximately 50,000 live infective juveniles (IJs) of $H$. pakistanensis.

The clay powder formulation of EPN was evaluated at 3 different concentrations, $15 \mathrm{~g}\left(7.5 \times 10^{5} \mathrm{IJs}\right), 20 \mathrm{~g}(1.0 \times$ $\left.10^{6} \mathrm{IJs}\right)$, and $25 \mathrm{~g}\left(1.25 \times 10^{6} \mathrm{IJs}\right)$. The treatments were accompanied with and without post wetting of tree trunk. Besides, these 6 treatments (T1-T6) and 1 treatment (T7) was included as untreated control. All the 10 banded tree trunks were made thoroughly wet (1 l of water/ tree trunk) with their respective treatments, using rose can sprinkler provided with a nozzle having small holes to break up the stream of water into small droplets. Application was performed in evening hours in order to allow the bands to remain moist for longer period unlike during sunshine hours for survival ability and aggressive foraging of EPN against over wintering larvae, during the last week of August, which marked termination of larval overwintering of Codling moth. Five trees of the treatment T2, T4, and T6 were provided post wetting by fresh water, after $12 \mathrm{~h}$ of EPN treatment and marked as "post wet."

\section{Collection and storage of dead larvae}

Thirty-six hours after EPN treatment, the trunk bands of all 10 trees were opened for collection of larvae present under the band, and/or under the bark of each tree, for post treatment count. Larvae collected from each treatment (with or without post wet) were kept separately in plastic container $(250 \mathrm{ml})$ half filled with moist soil. The container was brought safely to laboratory, placed in BOD (Bio-Oxygen Demand) incubator, maintained at $27 \pm 1{ }^{\circ} \mathrm{C}$.

Data regarding larval density per tree trunk, larval mortality after 48 and $72 \mathrm{~h}$, treatment wise and year wise was duly recorded for subsequent analysis.

Table 1 Effect of Heterorhabditis pakistanensis on percent larval mortality of Codling moth, Cydia pomonella, at Kargil during 2017 and 2018

\begin{tabular}{|c|c|c|c|c|c|c|}
\hline \multirow[t]{2}{*}{ Treatment } & \multicolumn{3}{|c|}{ Per cent larval mortality during 2017 after time intervals } & \multicolumn{3}{|c|}{ Percent larval mortality during 2018 after time intervals } \\
\hline & $48 \mathrm{~h}$ & $72 \mathrm{~h}$ & Cumulative mortality & $48 \mathrm{~h}$ & $72 \mathrm{~h}$ & Cumulative mortality \\
\hline $\begin{array}{l}\text { T1* } \\
(15 \mathrm{gms} / \mathrm{l}) \\
\left(7.5 \times 10^{5} \mathrm{Is}\right)\end{array}$ & $\begin{array}{l}43.47 \\
(41.53)^{b}\end{array}$ & $\begin{array}{l}3.09 \\
(10.85)^{b}\end{array}$ & $\begin{array}{l}46.57 \\
(43.60)^{b}\end{array}$ & $\begin{array}{l}36.22 \\
(37.25)^{b}\end{array}$ & $\begin{array}{l}4.90 \\
(13.33)^{b}\end{array}$ & $\begin{array}{l}41.13 \\
(40.43)^{b}\end{array}$ \\
\hline $\begin{array}{l}\mathrm{T} 2^{* *} \\
(15 \mathrm{gms} / \mathrm{l}) \\
\left(7.5 \times 10^{5} \mathrm{IJs}\right)\end{array}$ & $\begin{array}{l}57.12 \\
(49.58)^{c}\end{array}$ & $\begin{array}{l}6.34 \\
(15.12)^{c}\end{array}$ & $\begin{array}{l}63.47 \\
(53.84)^{c}\end{array}$ & $\begin{array}{l}46.05 \\
(43.00)^{b}\end{array}$ & $\begin{array}{l}6.95 \\
(15.35)^{b}\end{array}$ & $\begin{array}{l}53.00 \\
(47.31)^{b}\end{array}$ \\
\hline $\begin{array}{l}\text { T3* } \\
(20 \mathrm{gms} / \mathrm{l}) \\
\left(1.0 \times 10^{6} \mathrm{IJs}\right)\end{array}$ & $\begin{array}{l}54.92 \\
(48.15)^{c}\end{array}$ & $\begin{array}{l}10.45 \\
(19.24)^{d}\end{array}$ & $\begin{array}{l}65.37 \\
(54.69)^{c}\end{array}$ & $\begin{array}{l}53.04 \\
(47.36)^{\mathrm{bc}}\end{array}$ & $\begin{array}{l}8.85 \\
(17.53)^{b c}\end{array}$ & $\begin{array}{l}61.90 \\
(53.20)^{\mathrm{bc}}\end{array}$ \\
\hline $\begin{array}{l}\mathrm{T}^{* *} \\
(20 \mathrm{gms} / \mathrm{l}) \\
\left(1.0 \times 10^{6} \mathrm{IJs}\right)\end{array}$ & $\begin{array}{l}65.52 \\
(54.46)^{c d}\end{array}$ & $\begin{array}{l}10.75 \\
(19.57)^{d}\end{array}$ & $\begin{array}{l}76.28 \\
(61.91)^{d}\end{array}$ & $\begin{array}{l}58.74 \\
(50.45)^{c}\end{array}$ & $\begin{array}{l}9.56 \\
(18.41)^{c}\end{array}$ & $\begin{array}{l}68.31 \\
(56.84)^{c}\end{array}$ \\
\hline $\begin{array}{l}\mathrm{T5}^{*} \\
(25 \mathrm{gms} / \mathrm{l}) \\
\left(1.25 \times 10^{6} \mathrm{Is}\right)\end{array}$ & $\begin{array}{l}68.01 \\
(56.23)^{d}\end{array}$ & $\begin{array}{l}11.69 \\
(20.32)^{d}\end{array}$ & $\begin{array}{l}79.70 \\
(64.68)^{d}\end{array}$ & $\begin{array}{l}61.45 \\
(52.07)^{c}\end{array}$ & $\begin{array}{l}9.91 \\
(18.74)^{c}\end{array}$ & $\begin{array}{l}71.37 \\
(58.95)^{c}\end{array}$ \\
\hline $\begin{array}{l}T^{* *} \\
(25 \mathrm{gms} / \mathrm{l}) \\
\left(1.25 \times 10^{6} \mathrm{Is}\right)\end{array}$ & $\begin{array}{l}77.62 \\
(62.44)^{\mathrm{e}}\end{array}$ & $\begin{array}{l}12.49 \\
(20.89)^{d}\end{array}$ & $\begin{array}{l}90.12 \\
(73.69)^{\mathrm{e}}\end{array}$ & $\begin{array}{l}69.14 \\
(56.71)^{c d}\end{array}$ & $\begin{array}{l}13.28 \\
(21.31)^{c}\end{array}$ & $\begin{array}{l}82.43 \\
(66.93)^{d}\end{array}$ \\
\hline $\begin{array}{l}\text { T7 } \\
\text { (Untreated control) }\end{array}$ & $\begin{array}{l}3.69 \\
(11.67)^{\mathrm{a}}\end{array}$ & $\begin{array}{l}0.00 \\
(4.05)^{\mathrm{a}}\end{array}$ & $\begin{array}{l}3.69 \\
(12.39)^{\mathrm{a}}\end{array}$ & $\begin{array}{l}3.43 \\
(11.37)^{\mathrm{a}}\end{array}$ & $\begin{array}{l}0.00 \\
(4.05)^{a}\end{array}$ & $\begin{array}{l}4.43 \\
(12.10)^{\mathrm{a}}\end{array}$ \\
\hline$C D(0.05)$ & 5.49 & 2.27 & 6.66 & 6.41 & 3.74 & 7.55 \\
\hline$C V(5 \%)$ & 48.11 & 64.28 & 48.40 & 48.46 & 65.83 & 47.87 \\
\hline
\end{tabular}


Table 2 Two-years pooled data of cumulative larval mortality of Codling moth, Cydia pomonella, at Kargil during 2017 and 2018

\begin{tabular}{|c|c|c|c|c|}
\hline \multirow[t]{2}{*}{ Treatment } & \multicolumn{3}{|c|}{ Per cent larval mortality after time intervals } & \multirow{2}{*}{$\begin{array}{l}\% \\
\text { reduction } \\
\text { over } \\
\text { control }\end{array}$} \\
\hline & $48 \mathrm{~h}$ & $72 \mathrm{~h}$ & Pooled mortality & \\
\hline $\begin{array}{l}\text { T1* } \\
(15 \mathrm{gms} / \mathrm{l}) \\
\left(7.5 \times 10^{5} \mathrm{lJs}\right)\end{array}$ & $\begin{array}{l}39.85 \\
(39.42)^{b}\end{array}$ & $\begin{array}{l}4.00 \\
(12.19)^{b}\end{array}$ & $\begin{array}{l}43.85 \\
(41.74)^{b}\end{array}$ & $\begin{array}{l}41.78 \\
(40.25)^{\mathrm{a}}\end{array}$ \\
\hline $\begin{array}{l}\mathrm{T} 2 * * \\
(15 \mathrm{gms} / \mathrm{l}) \\
\left(7.5 \times 10^{5} \mathrm{lJs}\right)\end{array}$ & $\begin{array}{l}51.59 \\
(46.24)^{c}\end{array}$ & $\begin{array}{l}6.64 \\
(15.42)^{c}\end{array}$ & $\begin{array}{l}58.24 \\
(50.12)^{c}\end{array}$ & $\begin{array}{l}56.71 \\
(48.93)^{\mathrm{b}}\end{array}$ \\
\hline $\begin{array}{l}\text { T3* } \\
(20 \mathrm{gms} / \mathrm{l}) \\
\left(1.0 \times 10^{6} \mathrm{Js}\right)\end{array}$ & $\begin{array}{l}53.98 \\
(47.64)^{c}\end{array}$ & $\begin{array}{l}9.65 \\
(18.51)^{d}\end{array}$ & $\begin{array}{l}63.64 \\
(53.40)^{c}\end{array}$ & $\begin{array}{l}62.30 \\
(52.30)^{\mathrm{b}}\end{array}$ \\
\hline $\begin{array}{l}\mathrm{T} 4^{* *} \\
(20 \mathrm{gms} / \mathrm{l}) \\
\left(1.0 \times 10^{6} \mathrm{Js}\right)\end{array}$ & $\begin{array}{l}62.13 \\
(52.39)^{d}\end{array}$ & $\begin{array}{l}10.16 \\
(19.02)^{d}\end{array}$ & $\begin{array}{l}72.29 \\
(58.82)^{d}\end{array}$ & $\begin{array}{l}71.27 \\
(57.84)^{c}\end{array}$ \\
\hline $\begin{array}{l}\text { T5* } \\
(25 \mathrm{gms} / \mathrm{l}) \\
\left(1.25 \times 10^{6} \mathrm{IJs}\right)\end{array}$ & $\begin{array}{l}64.73 \\
(53.94)^{d}\end{array}$ & $\begin{array}{l}10.80 \\
(19.59)^{d}\end{array}$ & $\begin{array}{l}75.53 \\
(60.84)^{d}\end{array}$ & $\begin{array}{l}74.64 \\
(59.91)^{c}\end{array}$ \\
\hline $\begin{array}{l}\text { T6** } \\
(25 \mathrm{gms} / \mathrm{l}) \\
\left(1.25 \times 10^{6} \mathrm{lJs}\right)\end{array}$ & $\begin{array}{l}73.38 \\
(59.31)^{\mathrm{e}}\end{array}$ & $\begin{array}{l}12.89 \\
(21.17)^{\text {de }}\end{array}$ & $\begin{array}{l}86.27 \\
(68.96)^{\mathrm{e}}\end{array}$ & $\begin{array}{l}85.77 \\
(68.11)^{d}\end{array}$ \\
\hline $\begin{array}{l}\text { T7 } \\
\text { (Untreated control) }\end{array}$ & $\begin{array}{l}3.56 \\
(10.78)^{a}\end{array}$ & $\begin{array}{l}0.00 \\
(4.05)^{\mathrm{a}}\end{array}$ & $\begin{array}{l}3.56 \\
(10.78)^{\mathrm{a}}\end{array}$ & - \\
\hline $\mathrm{CD}(0.05)$ & 4.14 & 2.32 & 4.60 & 5.29 \\
\hline$C V(5 \%)$ & 44.95 & 61.21 & 44.42 & 24.27 \\
\hline
\end{tabular}

Each figure in column represents mean of five observations; figures in parentheses are a $\sin$ of $N+0.5$; similar superscripts in each column indicate the values statistically at par

*No post wetting

**Post wetting

\section{Confirmation of nematode killed larvae}

Change in larval color from original light pink to brick red indicated specifically Heterorhabditis induced mortality (Fig. 1). But for further confirmation, the dead insect larvae (cadavers) were placed on a White trap (White, 1927) for the release of infective juveniles.

\section{Statistical analysis}

Minitab 11.12 (Minitab LLC) was used to analyze the data for ANOVA. Percent larval mortality was determined by dividing the number of dead larvae from total number of larvae in a sample. Percent reduction over control was calculated by using Abbott's (1925) formula: $T-C / 100-C^{*} 100$ (where $T=$ mortality in treated condition and $C=$ mortality in untreated control condition)

\section{Results and discussion}

Effect of tree trunk banding and nematode on diapausing larvae

Gunny bags wrapped around the apple tree trunks provide an ideal shelter for overwintering and also protection from birds and other predators to the diapausing larvae of Codling moth. In a previous study at Kargil, where in apple tree trunks were banded by gunny bags, 35.37 to 99.56 overwintering larvae per tree trunk was observed (Ahmad et al. 2018). Similar trends were observed in the present experiment. The average larval density of Codling moth per tree trunk in the 2

Table 3 Analysis of variances of different treatments and Student's t-test during 2017 and 2018

\begin{tabular}{|c|c|c|c|c|c|c|c|c|c|c|}
\hline \multirow[t]{2}{*}{ Treatments } & \multicolumn{3}{|c|}{ Year 2017} & \multicolumn{3}{|c|}{ Year 2018} & \multicolumn{3}{|c|}{ Pooled mean } & \multirow[t]{2}{*}{ Student's $t$ test } \\
\hline & $F=$ & d.f. $=$ & $P=$ & $F=$ & d.f. $=$ & $P=$ & $F=$ & d.f. $=$ & $P=$ & \\
\hline After $48 \mathrm{~h}$ & $53.63^{* *}$ & 6.24 & 0.00 & $32.69 * *$ & 6.24 & 0.00 & $84.98^{* *}$ & 6.24 & 0.00 & $\begin{array}{l}t=0.97 \mathrm{NS} P=0.33 \\
\text { d.f. }=67\end{array}$ \\
\hline After $72 \mathrm{~h}$ & $44.18^{* *}$ & 6.24 & 0.00 & $13.39^{* *}$ & 6.24 & 0.00 & $38.22^{* *}$ & 6.24 & 0.00 & $\begin{array}{l}t=0.13 \text { NS } P=0.90 \\
\text { d.f. }=67\end{array}$ \\
\hline Total \% mortality & $52.22^{* *}$ & 6.24 & 0.00 & $32.96^{* *}$ & 6.24 & 0.00 & $78.17^{* *}$ & 6.24 & 0.00 & $\begin{array}{l}t=0.92 \mathrm{NS} P=0.36 \\
\text { d.f. }=67\end{array}$ \\
\hline
\end{tabular}


experimental years was found between 34.6 and 56.8 larvae/trunk (Fig. 2).

The larval population declined from 28.5 to 6.7 larave per tree trunk after nematode application (Fig. 2) exhibiting 43.85 to $86.27 \%$ mortality. When compared location wise, the larval density was found statistically different $(P \leq 0.01)$ from each other. Cumulative larval mortality during 2017 and 2018 varied from 46.57 to 90.12 and 41.13 to $82.43 \%$, respectively (Table 1 ). Pooled larval mortality ranged from 43.85 to $86.27 \%$ (Table 2) and was statistically different $(P \leq 0.01)$ with respect to treatments at 48 and $72 \mathrm{~h}$ interval. Similar observations were made when data was analyzed separately for each year (Table 3). Percent reduction in larvae over control ranged 41.78 to $85.77 \%$ with respect to different treatments of $H$. pakistanensis at concentrations between 7.5 $\times 10^{5} \mathrm{IJs}$ and $1.25 \times 10^{6} \mathrm{IJs} /$ tree (Table 2) and were statistically significant $(P \leq 0.01)$ from each other.

\section{Effect of nematode dosage on larval mortality}

An increase in EPN concentrations from $15 \mathrm{~g}$ to $25 \mathrm{~g}$ resulted in increasing larval mortality, indicating a strong positive correlation $\left(r=0.92^{* *}\right)$ between the 2 parameters (Table 2). This may be attributed to increase in the number of IJs with respect to increased dosage in water suspension, which maximized the chances of IJs encountering with diapausing larvae, resulting in higher larval mortality. Similar dosage dependent results were also reported by Lacey et al. (2005) who evaluated S. feltiae against Codling moth larvae and recorded $80 \%$ larval mortality at higher concentration of $50 \mathrm{IJs} / \mathrm{ml}$ of water in comparison to only 50 and $70 \%$ mortality at lower dose of 10 and $25 \mathrm{IJs} / \mathrm{ml}$ of water, respectively. The findings also confirm the report of Laznik et al. (2010) who found a high IJs concentration of $S$. feltiae applied in field against the Colorado potato beetle (Leptinotarsa decemlineata) significantly reduced the larval population of the pest as compared to the lowest IJs concentration.

\section{Nematode efficacy against larva on post-wet tree trunk} Increased performance of EPNs due to pre and postwetting has been reported by several workers (Cossentine et al. 2002 and De Waal et al. 2010). Similar trend was observed in the present study. Post-wetting, i.e., wetting of the tree trunk after $24 \mathrm{~h}$ resulted in maximum larval mortality than the non-post-wet (Table 2). This may be due to retaining of adequate moisture by the gunny wraps that enhanced mobility of nematodes, which in turn increased host finding ability and ultimately penetration of IJs into the host insect body. Comparison of data for larval mortality with respect to different treatments through Student's $t$ test between 2017 and 2018 however indicated non-significant differences (Table 3).
Apart from dosages used, several other factors like nematode application with rose can sprinkler during evening hours, optimum temperature of $18-23{ }^{\circ} \mathrm{C}$ during 3rd week of August in Ladakh Region and probably cold adapted nature of $H$. pakistanensis might have contributed in achieving high level of larval mortality. Reduced larval mortality with air blast spraying of EPNs during morning hours was reported by Lacey and Unruh (1998). Temperature between 15 and $25^{\circ} \mathrm{C}$ was reported to favor active host searching and penetration of EPN in diapausing larvae of Codling moth (Shapiro-Ilan et al. 2017), whereas at $14{ }^{\circ} \mathrm{C}$, activity of most of EPNs slow down (Odendaal et al. 2015), except the supremacy of cold adapted EPN species over warm adapted ones (Lacey et al. 2006).

\section{Conclusion}

In the present study, efficacy of $H$. pakistanensis NBAIR $\mathrm{H}-05$ against diapausing larvae of Codling moth provided encouraging results. Tree trunk banding for collecting diapausing larvae at one place and killing the larvae in masses by applying nematodes proved an excellent strategy for the management of Codling moth. $H$. pakistanensis NBAIR H-05, as a valuable biological component may be recommended in the integrated management program of Codling moth in Ladakh. In the long run, amalgamation of this cost-effective, eco-friendly tactics will certainly help to promote apple industry of Ladakh Region, if popularized at a large scale.

\section{Abbreviations}

NBAIR: National Bureau of Agricultural Insect Resources; SKUAST-K: Sher-eKashmir University of Agricultural Sciences and Technology of Kashmir; EC: Emulsified concentrate; IJs: Infective juveniles; EPN: Entomopathogenic nematode; BOD: Bio-Oxygen Demand

\section{Acknowledgements}

The present study was carried out under All India Coordinated Research Project on Biological Control of Crop Pests (ICAR- NBAIR). The agency is duly acknowledged for funding, supply of Heterorhabditis pakistanensis NBAIR H05 and support. The authors pay thanks to Director Research, SKUAST-K and Head, Division of Entomology, SKUAST-K, Shalimar campus, Srinagar, for providing necessary facilities required to conduct the experiment.

\section{Authors' contributions}

The design of the study was done by all the authors equally. The first author MJA analyzed the data and prepared the manuscript. The second author, SM, and third author, THA, evaluated the nematodes against codling moth on apple tree and collected the data. The fourth author JP supplied the nematode formulation. All authors read and approved the final manuscript.

\section{Authors' information}

Mohammad Jamal Ahmad is a Professor in Entomology and Incharge, Biocontrol Laboratory at SKUAST-K, India. Sajad Mohiddin is an Associate Professor, Entomology and Incharge Krishi Vigyan Kendra, Kupwara, SKUAST-K, India. Tarique Hassan Askary is an Assistant Professor in Entomology at SKUAST-K, India, and having specialization in nematology. Jagadeesh Patil is a Scientist Nematology in ICAR-NBAll, Bengaluru, India.

\section{Funding}

All India Coordinated Research Project on Biological Control of Crop Pests (ICAR-NBAIR). 


\section{Availability of data and materials}

All data generated or analyzed during this study are included in this article.

\section{Ethics approval and consent to participate}

Not applicable

\section{Consent for publication}

All authors read and approved the final manuscript.

\section{Competing interests}

The authors declare that they have no competing interests.

\section{Author details}

${ }^{1}$ Division of Entomology, Faculty of Horticulture, Sher-e-Kashmir University of Agricultural Sciences and Technology, Shalimar, Srinagar, Jammu and Kashmir 190025, India. ${ }^{2}$ Krishi Vigyan Kendra, SKUAST-K, Kupwara, Jammu and Kashmir, India. ${ }^{3}$ Division of Entomology, Faculty of Agriculture, Sher-e-Kashmir University of Agricultural Sciences and Technology, Wadura Campus, Sopore, Jammu and Kashmir 193201, India. ${ }^{4}$ ICAR-National Bureau of Agricultural Insects Resources, Bengaluru, Karnataka, India.

Received: 1 April 2020 Accepted: 13 May 2020

Published online: 26 May 2020

\section{References}

Abbott WS (1925) A method of computing the effectiveness of insecticide. Journal of Economic Entomology 18:265-267

Ahmad MJ, Mohiuddin S, Pathania SS (2018) Pheromone trapping and trunk banding: effective and eco-friendly approach for the management of codling moth, Cydia pomonella (Lepidoptera: Tortricidae) infesting apple in Ladakh. J Exp Zool 21:127-131

Blomefield TL (2003) Bionomics, behaviour and control of the codling moth, Cydia pomonella (L.) (Lepidoptera: Tortricidae), in pome fruit orchards in South Africa. PhD Thesis, Stellenbosch University, Stellenbosch, South Africa. http://scholar.sun.ac.za

Cossentine JE, Jensen LBJ, Moyls L (2002) Fruit bins washed with Steinernema carpocapsae (Rhabditida: Steinernematidae) to control Cydia pomonella (Lepidoptera: Tortricidae). Biocont Sci Tech 12:251-258

Cossentine JE, Sholberg PL, Jensen LBJ, Bedford KE, Shephard TC (2004) Fumigation of empty fruit bins with carbon dioxide to control diapausing codling moth larvae and Penicillium expansum Link. ex Thom spores. Hort Sci 39:429-432

De Waal JY, Malan AP, Levings J, Addison MF (2010) Key elements in the successful control of diapausing Codling moth, Cydia pomonella (Lepidoptera: Tortricidae) in wooden fruit bins with a South African isolate of Heterorhabditis zealandica (Rhabditida: Heterorhabditidae). Biocont Sci Tech 20:489-502

Giliomee J, Riedl H (1999) A century of codling moth control in South Africa: I. Historical perspective. J S Afric Soc Hort Sci 8:27-31

Hansen JD, Millie LH, Anderson PA (2006) Bin sterilization to prevent reintroduction of Codling moth. J Agril Urban Ent 23:17-26

Higbee BS, Calkins CO, Temple CA (2001) Overwintering of codling moth (Lepidoptera: Tortricidae) larvae in apple harvest bins and subsequent moth emergence. J Econ Ent 94:1511-1517

Lacey LA, Arthurs SP, Unruh TR, Headrick H, Fritts R (2006) Entomopathogenic nematodes for control of codling moth (Lepidoptera: Tortricidae) in apple and pear orchards: effect of nematode species and seasonal temperatures, adjuvants, application equipment, and post-application irrigation. Biol Cont 37:214-223

Lacey LA, Chauvin RL (1999) Entomopathogenic nematodes for control of diapausing codling moth (Lepidoptera: Tortricidae) in fruit bins. J Econ Ent 92:104-109

Lacey LA, Neven LG, Headrick HL, Fritts R (2005) Factors affecting entomopathogenic nematodes (Steinernematidae) for control of overwintering codling moth (Lepidoptera: Tortricidae) in fruit bins. J Econ Ent 98:1863-1869

Lacey LA, Unruh TR (1998) Entomopathogenic nematodes for control of codling moth: effect of nematode species, dosage, temperature and humidity under laboratory and simulated field conditions. Biol Cont 13:190-197

Laznik Ž, Tóth T, Lakatos T, Vidrih M, Trdan S. Control of the Colorado potato beetle (Leptinotarsa decemlineata Say) on potato under field conditions: a comparison of the efficacy of foliar application of two strains of Steinernema feltiae (Filipjev) and spraying with thiametoxam. J PI Diseas Prot. 2010;117: 129-135.

Malik RA, Punjabi AA, Bhat AA (1972) Survey study of insect and non-insect pests of Kashmir. Horticult 3:29-44

Odendaal D, Addison MF, Malan AP (2015) Entomopathogenic nematodes for the control of the codling moth (Cydia pomonella L.) in field and laboratory trials. J Helminthol 90:615-623

Shahnawaz M, Ahmed M, Arshad M, Hussain M, Khan SS (2014) Codling moth damage assessment in apple fruit and its management using insecticide bioassays. Eur. J Exp Biol 4:76-81

Shapiro-llan D, Arthurs SP, Lacey LA (2017) Microbial control of arthropod pests of orchards in temperate climates. In: Lacey LA (ed) Microbial Control of Insect and Mite Pests. Academic Press, London, UK, pp 253-267

Unruh TR, Lacey LA (2001) Control of codling moth, Cydia pomonella (Lepidoptera: Tortricidae) with Steinernema carpocapsae: effects of supplemental wetting and pupation site on infection rate. Biol Cont 20:48-56

White GF (1927) A method for obtaining infective nematode larvae from cultures. Sci 66:302-303

\section{Publisher's Note}

Springer Nature remains neutral with regard to jurisdictional claims in published maps and institutional affiliations.

\section{Submit your manuscript to a SpringerOpen ${ }^{\circ}$ journal and benefit from:}

- Convenient online submission

- Rigorous peer review

- Open access: articles freely available online

High visibility within the field

- Retaining the copyright to your article

Submit your next manuscript at $\boldsymbol{\nabla}$ springeropen.com 